\title{
Harmful Anti-Sex-Selective Abortion Laws Are Sweeping U.S. State Legislatures: Why do Some Pro-choice People Support Them?
}

By Sital Kalantry ${ }^{1}$

Anti-sex selective abortion laws punish medical professionals for performing abortions if they know that the patient's motive for the abortion relates to the predicted biological sex of the fetus. Since 2009, nearly half of all state legislatures have considered bills to prohibit sex-selective abortion. ${ }^{2}$ The majority of the U.S. House of Representatives voted in favor of a similar ban in 2012. ${ }^{3}$ That same year, anti-sexselective legislation was the second most proposed anti-abortion prohibition in the United States. ${ }^{4}$ Today ten states have enacted the bans, ${ }^{5}$ though they are (partially) unenforceable in three states. ${ }^{6}$

The laws stigmatize and stereotype Asian Americans, restrict women's access to non-selec tive abortion, and are likely unconstitutional. Yet, elected officials who are pro-choice have voted in favor of the bans. Liberal media sources wrongly report that Asian Americans are aborting female fetuses at rates similar to people in India and China. Pro-choice people appear to be torn about how to react to these particular abortion restric tions.

I attempt to explain this puzzling state of affairs here. I argue that pro-choice legislators and other people have been misled to support sex-selective abortion bans by misinterpretations of demographic data in a way that aligns with stereotypes about Asians and Asian Americans. In Section 1, I explain how legislation banning sex-selective abortion was driven by the findings of an academic article released in 2008 suggesting that sex-selective abortion was widespread among Asian Americans. Next, in Section 2, I explain why the laws are harmful to all women's right to choose. Through an analysis of the voting records of legislative representatives in Oklahoma and in the U.S. House of Representatives, I conclude that many pro-choice legislators voted in favor of sex-selective abortion restrictions in Section 3. Then, in Section 4, I analyze the findings of the 2008 article to demonstrate that their conclusions were misinterpreted to suggest that sex-selective abortion is widespread among Asian Americans when that is not the case. In Section 5, I present an analysis of census data that is more recent than the data that was used in the 2008 article and that challenges the dominant assumptions about the motives of the behavior of Asian Americans. Finally, in Section 6, I evaluate the constitutionality of sex-selective abortion bans.

\section{The Genesis and Justifications for Sex-selective Abortion Bans}

A two-page article published in 2008 by Douglas Almond and Lena Edlund, entitled "Son-biased Sex Ratios in the 2000 United States Census," started a legislative firestorm to ban sex-selective abortion. ${ }^{7}$ The article was published in the Proceedings of the National Academy of Sciences, an influential multidisciplinary science journal. By examining the ratio of boys to girls born to Asian Americans, they suggested that Asian Americans abort female fetuses at the same rates as people living in Asia. Specifically, the authors stated that "the magnitude of the deviations ... for second and third children of Chinese, Indian, and Korean Americans is comparable to that documented for India, China and South

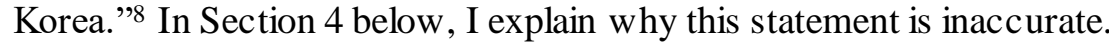

Bills began to be introduced in state legislatures almost immediately after the study was released, and they continue to be proposed today. In 2009, five state legislatures considered (and rejected) sex-selective abortion bans; in 2010 eight state legislatures considered the bans (one of them passed it); in 2011, five state legislatures considered the ban (one of them adopted it); in 2012, nine states considered the bill; and in 2013, sixteen states considered the bill (three states passed it). In 2014, ten states considered the ban (one state enacted it). Two more states have enacted bans since then. ${ }^{9}$ Table 1 below lists each state by the year that it adopted a statute to ban sex-selective abortion. 
Illinois and Pennsylvania are the only states that enacted sex-selective abortion bans prior to the publication of Almond and Edlund's article. In examining the transcripts of discussions of the bills in those state legislatures, I found that there was never any mention of the purported behavior of Asian Americans as a justification for the bills in those two states. The focus of the legislative discussion in those states was broadly on the sex-selective behavior of all Americans. ${ }^{10}$ The only time Asia was referred to in the legislative debates is when a pro-choice Pennsylvania senator pointed out that sexselection occurs in parts of Asia, but not in the United States. ${ }^{11}$

Table 1: States That Have Passed Anti Sex-Selection Abortion Laws

\begin{tabular}{|l|l|}
\hline State & Year of Enactment \\
\hline Illinois & 1984 \\
\hline Pennsylvania & 1989 \\
\hline Oklahoma & 2010 \\
\hline Arizona & 2011 \\
\hline Kansas & 2013 \\
\hline North Carolina & 2013 \\
\hline North Dakota & 2013 \\
\hline South Dakota & 2014 \\
\hline Indiana & 2016 \\
\hline Arkansas & 2017 \\
\hline
\end{tabular}

But since 2009, the bills that have been introduced specifically cite Almond and Edlund's article and claim that bans are necessary to prevent widespread discriminatory abortions of female fetuses. For example, the preamble of the bill proposed in the U.S. Congress in 2017, the Prenatal Nondiscrimination Act (PRENDA) of 2017 states:

In a March 2008 report published in the Proceedings of the National Academy of Sciences, Columbia University economists Douglas Almond and Lena Edlund examined the sex ratio of United States-born children and found "evidence of sex selection, most likely at the prenatal stage." 12

PRENDA further suggests that the data in Almond and Edlund's article "reveal[s] obvious 'son preference' ... within . . . segments of the United States population . . . tracing their origins to countries where sex-selection abortion is prevalent."13

The preambles of bills introduced in state legislatures also contain the same language quoted above. ${ }^{14}$ The political rhetoric of politicians that support the bills further refer to Asian immigration as a justification for the bans. ${ }^{15}$ For example, Don Hagger, a Republican state representative in South Dakota, stated:

Let me tell you, our population in South Dakota is a lot more diverse than it ever was. There are cultures that look at a sex-selection abortion as being culturally okay. And I will suggest to you that we are embracing individuals from some of those cultures in this country, or in this state. And I think that's a good thing that we invite them to come, but I think it's also important that we send a message that this is a state that values life, regardless of its sex. ${ }^{16}$

The narrative used to justify the laws can be summarized as follows: (1) people in Asia prefer sons and that is why they abort female fetuses, (2) Asians have emigrated to the United States and many of them obtain sex-selective abortions, (3) Asian Americans obtain these abortions because (like Asians) they 
have a sexist preference for sons and an aversion to daughters, and (4) sex selection in both the United States and Asia is discriminatory. I explain below why these assumptions are inaccurate.

\section{The Bans Impact Every Woman's Right to Choose}

Medical professionals are required to enforce bans on sex-selective abortion. A doctor who has know ledge that a woman is seeking an abortion due to the sex of the fetus will face criminal liability in most of the states that ban sex-selective abortion. ${ }^{17}$ But what if an abortion-seeker does not volunteer her motive, how will a medic al professional know about them? Because the rhetoric around the bills targets Asian Americans, it is possible that doctors will inquire about the motives of Asian American women or deny them reproductive care altogether for fear of their own liability. But this inquiry will be made of every woman in some states.

Many states require medical professionals to inquire about the motives of all abortion-seekers. For example, South Dakota's law banning sex-selective abortion requires medical professionals to "[i]nquire into whether the pregnant mother knows the sex of her unborn child and if so, whether the mother is seeking an abortion due to the sex of the unborn child." 18 Oklahoma requires medical professionals to complete a form for each abortion, which includes a section on the reasons a w oman obtained the abortion. ${ }^{19}$ In Arizona, while the law does not require inquiry, it motivates the medical professional to ask questions about the motive for any abortion because he or she must sign an affidavit certifying that he or she "is not aborting the child because of the child's sex or race and has no know ledge that the child to be aborted is being aborted because of the child's sex or race." 20 Arizona also requires health care professionals to report "known violations ... to appropriate law enforcement authorities."21 This kind of inquiry can be humiliating and invasive for a woman who is already embarking upon what is likely a difficult decision.

The most recent state to adopt a ban, Arkansas, went further than any other state. It requires medical professionals to ask each patient whether she knows the predicted future sex of the fetus and if she answers in the affirmative, then the professional must spend "time and effort" seeking her entire pregnancy-related history (including prior pregnancies). ${ }^{22}$ This means that any woman who is aware of the predicted biological sex of the fetus may suffer long delays in receiving reproductive care.

Sex-selective abortion bans create a wedge in the patient-doctor relationship because they require medical professionals to enforce them. This may lead to doctors denying Asian Americ an women reproductive care. But it is not just Asian Americ an women who are impacted; all women in some states that have adopted such bans must now be subjected to inquiry about their motives for seeking an abortion to rule out sex selection as the motive. One state adds a time delay in receiving an abortion to any woman who happens to know the predicted biologic al sex of her fetus. Laws that interfere with the patient-doctor relationship in such a way jeopardize the quality of health care services.

\section{Some Pro-choice Legislators Support the Harmful Abortion Restrictions}

Despite the fact that sex-selective abortion legislation will restrict even non-selective abortion and the scale and reality of gender-biased sex selection among Asian Americ ans is grossly exaggerated (as discussed in Section 4 below), several pro-choice national and state legislative representatives have supported the harmful legislation. In 2012, when the majority of the U.S. House of Representatives voted in favor of a Federal law prohibiting sex-selective abortion, twenty Democrats voted with the majority. ${ }^{23}$ Most people assume that Republicans are pro-life and most Democrats are pro-choice, but that is not always the case. I focus on the prior voting records of the Democrats in the U.S. House of Representatives who voted in favor of the Federal ban as a proxy for their political position on the right to choose. The prior voting records of the Democrats that voted for the Federal ban show that some of them generally 
voted in favor of abortion restrictions. Thus, many of them were likely pro-life and would vote in favor of any abortion restrictions. Thus, their vote in favor of banning sex-selective abortion is not particularly surprising.

However, eight of the Democrats who voted in favor of sex-selective abortion bans had mixed voting records - they sometimes voted against anti-abortion legislation and sometimes voted in favor of it. ${ }^{24}$ Two of those Democrats were avowedly pro-choice. ${ }^{25}$ One of the Democrats, Representative Garamendi, had stated: "I am a strong pro-choice feminist and a proud father of 5 daughters and 3 granddaughters! My daughters and wife are my closest advisors and confidants and all of my decisions are heavily weighed by their influence." 26 Thus, it appears that Democrats who never voted in favor of abortion restric tions but did vote in favor of restricting sex-selective abortion have accepted the narrative about Asian Americans put forw ard by pro-life advocates.

Even in state legislatures that enacted bans on sex-selective abortion, we observe pro-choice Democrats voting in favor of them. We see the largest number of pro-choice Democrats voting for the bans in Oklahoma, the first state to adopt the restriction after Almond and Edlund's article was published. In Oklahoma, nearly 90 percent of Democrats in both the House and Senate voted for the ban, which is a total of 61 Democrats. Of these Democrats voting to ban sex-selective abortion, 28 consistently vote to limit abortion access. However, 17 consistently vote against bills that limit abortion access and 8 have a mixed voting record. Thus, 25 pro-choice Democrats and on-the-fence Democrats voted in favor of adopting restriction on sex-selective abortion in Oklahoma. ${ }^{27}$

\section{Misinterpretations of Demographic Data about Asian Americans}

Many people in the United States who otherwise support access to abortion may be conflicted about how to react to sex-selective abortion bans because women's equality is implicated by both its practice and its prohibition. Sex-selective abortion appears to be discriminatory (at least in some situations) and prohibition of such abortion restricts reproductive rights. ${ }^{28}$ One person commenting on a story in the Atlantic on sex-selective abortion stated, "I lean pro-choice, but I doff my hat to the pro-life camp for this deft maneuver. They have demonstrated that it is logic ally impossible to be both 'pro-choice' and 'antidiscrimination." "29 I argue that pro-choice legislators and others have been misled into supporting sexselective abortion bans through misinterpretations of demographic data to align with stereotypes about Asians and Asian Americans.

As described above, Almond and Edlund's article sparked the enactment of laws across the American states to ban sex-selective abortion. The authors analyzed the genders of children born in the United States to parents that were born in China, Korea and India. They obtained this data from the publiclyreleased sample of the 2000 U.S. Census, which is only $5 \%$ of the overall census data. They came up with a ratio of boys to girls of the first child of Chinese, Koreans and Indians, then the ratio for the second child and for the third child for these groups. They found that the first child born to Chinese, Indian, and Korean parents was just as likely to be a male as the first child born to Caucasian families: the sex ratio of both groups was 1.05 , which was considered to be the biologic ally normal sex ratio. ${ }^{30}$

How ever, the authors found that the sex ratio of second children of Asian American families that had one prior girl child was more male-biased (1.17) than the sex ratio of second children of Caucasian Americ ans who had one prior girl child (1.05). ${ }^{31}$ For the third child, the ratio of boys to girls was even more malebiased in those Asian Americ an families that had two prior girl children. The sex ratio of the third child for these parents who had two prior girl children was 1.51. ${ }^{32}$ The sex ratio at the second and third births was considered abnormal because it deviated from the sex ratio of Caucasian American families at this level, which was again $1.05 .^{33}$ 
The same day Almond and Edlund's findings were published, National Public Radio (NPR) aired an interview with Professor Almond. When asked to provide an explanation of their findings, Professor Almond stated:

To us, given the context that in certain Asian countries there's a traditional preference for sons, that desire of sons is being exercised not only in Asia but in the United States, and that the technologies for prenatal sex determination, there's now evidence that those are being used to generate male birth. ${ }^{34}$

Numerous media stories also claimed that the findings of the article suggested that Asian Americans prefer to have sons. For example, the headline in a story in the International Herald Tribune states "Asians Show Bias for Boys; Census Data on Births Also Reflects Embrace of Sex Selection." 35 Even authors that provided a more careful analysis than the sensationalism of daily new spapers accepted the view that sex selection was occurring among the Asian Americ an community at crisis proportions. ${ }^{36}$

But simply by looking at the sex ratios that Almond and Edlund reported, it is not obvious how many cases of sex selection the authors are actually claiming occur. The authors never revealed that number. Instead, they noted that that "the magnitude of the deviations ... for second and third children of Chinese, Indian, and Korean Americans is comparable to that documented for India, China and South Korea." 37 This statement is part of the reason reporters concluded that there was a sex selection crisis in the United States similar to the one oc curring in Asia. For example, a story in Slate entitled "Fetal Subtraction: Sex selection in the United States" suggested that technological advancements could contribute to long-lasting cultural traditions of sex selection such as those in the Almond and Edlund study. ${ }^{38}$ But this prevailing understanding of a sex selection crisis in the United States is not accurate.

Recall that Almond and Edlund's analysis found that the sex ratio of the third child of Chinese, Indian, and Korean Americans is 1.51 (i.e. the number of male children born for every female child). ${ }^{39}$ They then argue that this figure is similar to the sex ratio in India. They point out that "[a]s a comparison, for India, the corresponding figure was found to be 1.39:1." 40 They are correct that the third births of Asian Americ ans and Indians seem to have a very similar sex ratio (1.51 for Asian Americans and 1.39 for Indians). But this comparison of only the third births of the children of Asian Americ ans and people living in India is misleading because it is only shows half the picture.

The full picture comes from comparing the second births of Asian Americans with the second births of people living in India. The sex ratio for second births of Asian Americans is 1.17 when parents have previously had a girl. ${ }^{41}$ On the other hand, the sex ratio for the second birth of Indians is 1.32 when parents have previously had a girl. ${ }^{42}$ Thus, the sex ratio of Indians at the second birth is far more maleskewed than that of Asian Americans. A significant amount of sex selection occurs at the second birth in India when there is one prior girl child, but sex selection is rarer in the United States at the second birth in the three Asian American communities.

The conclusion they draw from the comparison of the Asian Americ an sex ratios to the sex ratio in China is also inaccurate. They point out that the overall sex ratio in China is $2.25: 1 .{ }^{43}$ But this sex ratio is signific antly more male-skewed than the sex ratio for Asian Americans that they articulated (which was $1.51)$.

The comparison to Asian Americ an sex ratios and the sex ratio in South Korea is inaccurate for another reason - the sex ratio was actually balanced in South Korea at the time of their article (and continues to be so today). ${ }^{44}$ South Korea is often cited as a sex ratio success story in Asia for eradic ating sex selection. ${ }^{45}$ Yet, while ratios were balanced in South Korea, the ratios among Korean Americans (when combined with Indian and Chinese Americans) were male-skewed. Consequently, unlike what Almond and Edlund 
stated, the magnitude of sex selection was hardly the same among Asian Americans as that of people living in China, India, and South Korea at the time they published their article. It was far more maleskewed in India and China and far less in South Korea.

Although the economists never reported the number in their article, from simple calculation we can determine that they found that there were about 2,500 "missing" Asian American girls. Similarly, Jason Abrevaya, a professor in the economics department at the University of Texas, reports that he thinks there were "2,000 'missing girls' in the United States between 1991 and 2004."46 In 2011, James Egan, with his coauthors, estimated that there were 1000 missing girls per year across the entire United States from 1983 to $2002 .{ }^{47}$ This is a small fraction of the total Asian American population in the United States, which, according to the latest U.S. Census, is more than 17 million people. ${ }^{48}$ By way of comparison, there are over 60 million girls "missing" just in India. ${ }^{49}$ Moreover, based on their research, Almond and Edlund can only find deviations in sex ratios but cannot explain how they are occurring. People in the United States can sex-select using pre-implantation means such as sperm-sorting and in vitro fertilization combined with Preimplantation Genetic Diagnosis (PGD). ${ }^{50}$

Cutting the data a different way to compare the overall sex ratios across all children of Asian Americans to people in China and India, we can see even more clearly that sex ratios in China and India are signific antly male-biased but they are in the normal range among foreign-born Indian and Chinese people living in the United States.

Figure 1: Sex ratios of Asian American and Asians

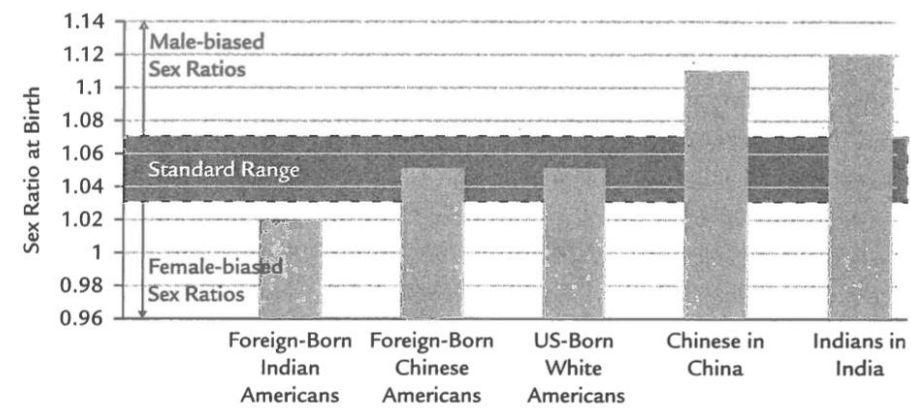

Source: Sital Kalantry \& Miriam Yeung, Replacing Myths with Facts: Sex-Selective Abortion Laws in the United States, University of Chicago Law School International Human Rights Clinic, National Asian Pacific Women's Forum, Advancing New Standards for Reproductive Justice (2014), available at https://ihrclinic.uchicago.edu/page/replacing-myths-facts-sex -selective-abortion-laws-united-states.

There is a general perception that data is neutral. However, the methodology researchers use, the questions they ask, and the conclusions they reach from the data are influenced by their own and society's biases. ${ }^{51}$ How researchers themselves and readers of the research interpret data is also influenced by their own previously held views.

\section{Stereotypes about Asians and Asian Americans}

A number of misperceptions about Asians, Asian Americans, and the motives for sex selection in Asia has lead to a widespread misunderstanding of narrow demographic data to conclude that there is a sex ratio crisis in the United States among Asian Americans. First, some people may have assumed that just because people who come from Asia and live in the United States look the same as people who live in their countries of origin, they share the same behavioral traits. The argument goes that if people widely 
abort female fetuses in Asia, they must also be doing so in the United States once they move to that country. Of course, while some behaviors of immigrants may be similar to people in their countries of origin, it is a form of stereotyping to assume that Asian Americans act in the same way as Asians. Moreover, the longer immigrants remain in the United States, the more their traits and behaviors may begin to deviate from people in their country of origin.

Second, some people may have readily accepted the view that sex selection both in parts of Asia and the United States is caused by sexism. There is a general perception that foreign cultures are inherently sexist and this view finds some support in feminist thought. ${ }^{52}$ When certain practices occur in immigrant cultures, they are seen to be motivated by a misogynist culture, but the same practice when it appears among the majority group does not lead people to make broad conclusions about that culture. Rather it is seen as an exception. ${ }^{53}$

A closer examination of the trends in India, ${ }^{54}$ however, paints a more nuanced picture of the reasons for sex selection and women's motives. In India, sex selection started on a significant scale only when Americ an ultrasound machines were shipped to India in the 1980s. ${ }^{55}$ Although against the common presumptions, sex ratio data as well as survey data suggests that there is not widespread "daughteraversion" but that what many (but not all) Indian families want to have is at least one boy. Some people want to have at least one son for economic support during old-age, to carry on the family name, and to perform certain death rituals for their parents.

For people living in poverty, a daughter can be expensive as she must be clothed and fed but is less likely to contribute to the financial welfare of the family and may instead require signific ant expense in the form of a dowry or payment to the family of the man she marries. Technology, combined with the desire to have fewer children, and the cultural preference to have at least one son, leads to many women each year to illegally learn the sex of their fetuses and deciding to abort female fetuses if they already have one or two prior girl children.

Third, there is a failure to recognize that just because a practice is discriminatory in one context, it may not be discriminatory in another. In addition, it is often assumed that the behavior of immigrants (unlike the majority community) is driven by deep-seated cultural beliefs rather than the product of the social and economic context in which they are living.

To illustrate my point, I compare two scenarios. Take the case of an Indian woman living in India who takes steps to have a boy child after she has had a girl child and the case of a woman of Indian descent in the United States who takes steps to have a boy after she has a girl. The first scenario in India raises different concerns than the second one. Social institutions such as dowry, patrilocal forms of marriage, and few er economic opportunities for girls, are some reasons why families may want to have at least one boy child in India. When families play into this tradition, they further perpetuate and reinforce those customs. What is more troubling is that emerging empirical studies have found that the male surplus is harming women in other ways. Some emerging studies suggest that there are higher levels of sexual harassment, rape and early child marriage in districts where there is greater sex selection. ${ }^{56}$

In the case of an immigrant woman in the United States, the context in which her act occurs is different. She will not likely be required to pay money to a groom to marry her daughter, she can rely on social security and other state support rather than relying solely on her son for economic support in old age, and there is no prevailing custom against daughters providing economic support. Her daughter born in the United States may have more economic opportunities for self-sufficiency than one born in India. Large numbers of people in the United States are not systematically selecting in favor of boys. Given that there is no male-surplus in the United States, there are no consequences that relate to imbalanced sex ratios (such as increased sexual harassment and rape) that occur. Moreover, as I discuss below, the few Asian 
Americ an people who might be intervening to obtain the family composition they desire are not necessarily doing so for the same motives as people living in Asia.

In this section, I have outlined some of view s about Asians and Asian Americ ans and culture and context that may have primed some Americ ans to more readily accept misrepresentations of academic studies to fit comfortably into certain stereotypes. I elaborate this point elsew here. ${ }^{57}$ In the next section, using newer demographic data as well as survey data, I argue that the reasons for the behavior of some Asian Americans may be very different than the actions of some Asians.

\section{Beyond "Son Preference"}

The data used in Almond and Edlund's study is from the U.S. Census of 2000. In 2014, I worked with an interdisciplinary team to conduct an empiric al analysis on sex ratios based on U.S. Census data from 2008 to 2012 and found something that had not been previously observed. ${ }^{58}$

Like Almond and Edlund, we found that when foreign-born Chinese, Korean, and Indian parents have two girls, the sex ratio of the third child shows a male-bias (1.33). However, unlike Almond and Edlund's study, we found that in more recent data, the sex ratio of the third child of Chinese, Korean, and Indian parents in the United States is female-biased after they have had two boys (0.89) (see Figure 2). This suggests that a very small number of Chinese-, Korean-, and Indian-American families are taking measures to ensure that they have both boy children and girl children in their families.

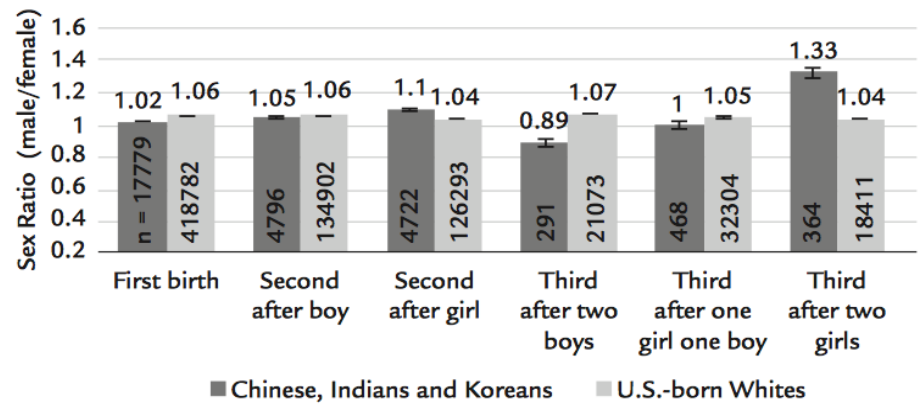

Figure 2. Comparison of Sex Ratios of Chinese, Indian, and Korean Children and U.S.-Born Caucasian Children (2008-2012 ACS).

Source: Analysis of pooled American Community Survey data from 2008 to 2012.

Sex ratio research has certain limitations. As noted above, even where researchers find imbalanced sex ratios, those ratios do not tell us what methods are being used for sex-selection-preimplantation methods or abortion. In addition, from demographic data, we cannot determine the motivations for people's behavior. To ascertain what motivates the behavior of Asian Americans, I included two questions in an annual national survey conducted by the Cornell Survey Research Institute (Cornell SRI). In total, 1000 households were surveyed. By way of comparison, the most recent Gallup Poll survey on gender preferences surveyed 1020 people nationally using a similar methodology. ${ }^{59}$ In these two questions, I asked respondents their gender preference if they could only have one child, and if they could have only two children.

Consistently across each racial and ethnic group, more respondents said they would prefer to have a son than a daughter if they could have only one child as can be observed in Table 2 . In the Cornell SRI poll, only $18.8 \%$ of the Asian Americ ans surveyed said they w ould want to have a boy if they could only have one child. Similarly, $16.8 \%$ of Caucasian Americans said they would want a boy if they could have only one child. On the other hand, a signific antly greater percentage of Native Americans (28.6\%) 
and African Americans (32.7\%) indicated they would want a boy if they could have a boy. Across all groups, fewer numbers wanted to have a girl if they could have only one child. Thus, when asked about their attitudes, Asian Americans do not manifest a greater preference for sons than any other racial group in the United States.

When the respondents are told they can have two children, 5\% of Caucasian Americans want two boys and $2.7 \%$ want only girls. If this disparity were observed among Asian Americans, some might see this as proof of "son preference," but few would interpret this to mean "son preference" among Caucasian Americans. Contrary to the dominant narrative of "son preference" among Asian Americans, 6.3\% of Asian Americans want only boys and an equal percentage - 6.3\% - want only girls when they are told they can have only two children.

The most important finding is that $60.4 \%$ of Asian Americans want to have one boy and one girl if they could have only two children. The desire for gender balance is greater among Asian Americans than any other group. Approximately 58\% of African Americans desire a gender-balanced family, whereas only $49.4 \%$ of Caucasian American desire a gender-balanced family. Still, a quarter of the Asian Americ ans surveyed stated that they have no preference for the gender composition of their children. These results are consistent with another poll conducted by the Cornell Survey Research Institute in 2015 among New York State residents only, the state with the second largest Asian American population. ${ }^{60}$

An analysis of new demographic data combined with survey data tells a different story about Asian American reproductive patterns. One plausible interpretation of the sex ratio and survey data is that Asian Americans desire both boy children and girl children. A few Asian families who have three children may have inter vened to achieve balanced families. While there may be a small number of Asian Americans who still desire to have at least one son out of their "cultural" preference, this is a small group of people. It is not nec essary to pass legislation that has a negative impact on all women just to attempt to prevent the behavior of a small minority of people who may not even be acting because of "sexist" motives.

\section{Table 2: Results of a Poll of U.S Residents on Gender Preferences}

\begin{tabular}{|l|c|c|c|c|c|}
\hline & $\begin{array}{c}\text { Caucasian } \\
\text { Americans }\end{array}$ & $\begin{array}{c}\text { Asian } \\
\text { Americans }\end{array}$ & $\begin{array}{c}\text { African } \\
\text { Americans }\end{array}$ & $\begin{array}{c}\text { Native } \\
\text { Americans }\end{array}$ & Other \\
\hline If you could have only one child: & & \\
\hline Boy Only & $16.8 \%$ & $18.8 \%$ & $32.7 \%$ & $28.6 \%$ & $19.0 \%$ \\
\hline Girl Only & $11.2 \%$ & $10.4 \%$ & $15.0 \%$ & $8.2 \%$ & $4.8 \%$ \\
\hline Don't Care & $66.1 \%$ & $66.7 \%$ & $47.8 \%$ & $59.2 \%$ & $66.7 \%$ \\
\hline $\begin{array}{l}\text { Don't Want } \\
\text { Children }\end{array}$ & $5.9 \%$ & $4.2 \%$ & $4.4 \%$ & $4.1 \%$ & $9.5 \%$ \\
\hline If you could have only two children: & $6.3 \%$ & $8.0 \%$ & $18.4 \%$ & $0.0 \%$ \\
\hline \begin{tabular}{l|c|c|c|c|c|} 
Only Boys \\
\hline Only Girls
\end{tabular} & $2.7 \%$ & $6.3 \%$ & $6.2 \%$ & $2.0 \%$ & $0.0 \%$ \\
\hline $\begin{array}{l}\text { One Boy/ } \\
\text { One Girl }\end{array}$ & $49.4 \%$ & $60.4 \%$ & $58.4 \%$ & $44.9 \%$ & $52.4 \%$ \\
\hline Don't Care & $38.2 \%$ & $25.0 \%$ & $24.8 \%$ & $34.7 \%$ & $42.9 \%$ \\
\hline $\begin{array}{l}\text { Don't Want } \\
\text { Children }\end{array}$ & $4.7 \%$ & $2.1 \%$ & $2.7 \%$ & $0.0 \%$ & $4.8 \%$ \\
\hline $\begin{array}{l}\text { Total } \\
\text { Respondents }\end{array}$ & 768 & 48 & 113 & 49 & 21 \\
\hline
\end{tabular}

Source: Poll conducted by the Cornell Survey Research Institute Poll 2015.

Some pro-choice people may find sex selection for both girls and boys problematic. First, people informed by postmodern and queer theories may oppose sex selection because it supports the idea of 
gender as a binary category - male or female. ${ }^{61}$ Another possible argument against sex selection is that people who sex-select are more likely to force their children to conform to traditional gender expectations and roles. ${ }^{62}$ Yet another possible argument against sex selection posits that by sex-selecting, parents make a statement that one sex is superior to another. Although people who are uneasy with sex-selective abortion may not necessarily support sex-selective abortion bans, their ambivalence about the practice of sex selection may weaken their opposition to such bans.

In the prior section, I have argued that the scale of sex-selective abortion among Asian Americans was widely exaggerated in popular discourse. It was as sumed this behavior was driven by misogyny and daughter-aversion. The data presented in this section adds another layer to the dominant narrative. If Asian Americ ans are sex-selecting (which we cannot know for certain and also cannot know what methods they are using), their motives may relate to balancing their families with both genders. In the next section, I explain why sex-selective abortion bans are likely unconstitutional.

\section{Sex-Selective Abortion Bans are Likely Unconstitutional}

The U.S. Supreme Court may soon be asked to determine whether or not the anti-sex-selective abortion laws passed by the ten U.S. states are constitutional. ${ }^{63}$ U.S. jurisprudence on abortion forms a complicated web of decisions. Given this complexity, we cannot be certain what legal test the Supreme Court ("Court") will use in evaluating the constitutionality of the prohibitions on sex-selective abortion. The composition of the justices will also drive what test is used and what conclusion is reached. There is no consensus among legal scholars about what legal test the Court will use let alone how they will rule. ${ }^{64}$

One approach the Court might take is to distinguish between pre-viability and post-viability sex-selective abortion bans. ${ }^{65}$ While it would prohibit all pre-viability restrictions, it would evaluate post-viability bans using the approach articulated in its most recent abortion case, Whole Woman's Health v. Hellerstedt. ${ }^{66}$ In that case, in determining whether the abortion restrictions in question were an "undue burden" the court used a cost/benefit analysis test. ${ }^{67}$ In the case of sex-selective abortion bans, whether it decides that the benefits of the bans exceed the costs depends on which narrative it believes - the one I have articulated above or the one advanced by pro-life groups and accepted by some pro-choice people based on the misinterpretation of narrow data provided in the Almond and Edlund study.

In a recent decision, a Federal judge declared Indiana's sex-selective abortion statute unconstitutional. Judge Pratt granted a permanent injunction against the enforcement of Indiana's sex-selective abortion prohibition as well as its ban on disability-selection and race-selection abortion (collectively, "antidiscrimination" provisions). ${ }^{68}$ She also declared that the anti-discrimination provisions, to the extent they apply pre-viability, are unconstitutional. ${ }^{69}$ The state of Indiana has appealed this judgment to the Federal Court of Appeals for the Seventh Circuit. ${ }^{70}$ The party that loses in the Federal Court of Appeals can file a petition asking the Supreme Court to review the appeals court decision though the Court is not required to hear the case.

The foundational decision that established that the right to choose was Roe $v$. Wade..$^{71}$ It established different legal tests based on the number of weeks of gestation. ${ }^{72}$ Judge Pratt interpreted Roe to mean a state was not permitted to restrict pre-viability abortion in any way. She stated that " $[\mathrm{t}]$ he woman's right to choose to terminate a pregnancy pre-viability is categorical: 'a State may not prohibit any woman from making the ultimate decision to terminate her pregnancy before viability." 73

Nearly a quarter of a century before the Indiana decision, the State of Illinois had settled a similar suit against its ban on sex-selective abortion. Illinois agreed that the statute should only apply post-viability after the Supreme Court's decision. ${ }^{74}$ In rejecting an objection to this settlement, the United States Federal Court for the Northern District of Illinois stated that " $[\mathrm{t}]$ he Casey court made it clear that any pre-viability 
regulation which imposes a palpable restriction on a women's right to elect abortion would be prohibited." 75 Thus, at least one other court has suggested that pre-viability sex-selective bans are unconstitutional. The Federal Court of Appeals for the Ninth Circuit has also found that pre-viability bans on abortion are generally unconstitutional. ${ }^{76}$

Even if it decides that pre-viability restrictions are categorically impermissible under Roe $v$. Wade, the Court might treat post-viability abortions differently. It could use the "undue burden" test to evaluate the constitutionality of the bans post-viability. In 1993 in Casey, the Court established a new legal test - the "undue burden" test. The Court found that states could enact restric tions as long as they did not create an "undue burden" on the right to choose. ${ }^{77}$ The most recent important interpretation of "undue burden" is in Whole Woman's Health v. Hellerstedt. ${ }^{78}$ In that case, the Court evaluated two Texas regulations. ${ }^{79}$ The first regulation required medical professionals who perform abortions to have admitting privileges at a hospital within 100 miles of the abortion site. ${ }^{80}$ The other regulation requires abortion clinics to satisfy the state requirements imposed on surgical centers. ${ }^{81}$ The Court framed the "undue burden" test as a cost/benefit analysis. ${ }^{82}$

Supporters of the legislation argued that strict health regulations were needed to protect the health of abortion-seekers. How ever, the Court found that the Texas restrictions have no benefits since abortions are already fairly safe procedures in Texas ${ }^{83}$ On the other hand, they impose significant costs on women's access to abortion given that scores of clinics had already closed in Texas as a result of the statute. ${ }^{84}$ The Court emphasized the need to consider factual findings, rather than merely the law's purported benefits, when engaging in this analysis. ${ }^{85}$ Thus, applying a cost/benefit test, the Court found that the Texas restrictions imposed an undue burden on abortion access and were therefore unconstitutional. ${ }^{86}$

In light of Whole Woman's Health, the Court will likely undertake a cost/benefit analysis if it applies the "undue burden" test to post-viability sex-selective abortion bans. I have described the costs of the ban in Section 2 above. To recap: sex-selective abortion bans will create a tension in the relationship between a medical professional and her patient, could lead to racial profiling by medical professionals, and will burden the rights of women who desire to obtain non-selective abortions.

According to pro-life advocates, there are two key benefits of bans on sex-selective abortion. First a ban will address a widespread practice (targeted abortion of female fetuses). As discussed in Sections 4 and 5, by relying on stereotypes about the behavior of Asian Americans and drawing on misinformation about foreign countries and misunderstandings of empirical data, some people argue that gender-biased abortion occurs in crisis proportions in the United States. The truth is that, at most, sex ratio data suggests that a few thousand Asian Americans sex selected because they wanted boy-children when they already had one or two girl-children. Even if we assume that every single one of these people selected against a girl, it is possible that each of these people used sperm-sorting or IVF and PGD to manipulate the gender of their children rather than abortion. A small number of other Asian Americans may also be selecting in favor of girls.

Second, some people argue that the aborting of female fetuses in the United States is problematic because the motives of the people who do it are discriminatory. This conclusion draws on information about what is believed to motivate gender-biased abortion in foreign countries. In Section 6, I explain using more recent data on Asian Americ an childbirths that there are a small number of people who select in favor of girls when they have prior boy-children. This challenges the notion that those Asian Americans who sex select are manifesting sex discrimination - rather, it suggests that they desire families with both genders. A survey of Americans confirms that Asian Americ ans are the group that is most likely to want a family with at least one boy and one girl. One could morally object to family balancing, but that practice does not manifest discrimination against women and girls in the same way as in parts of Asia. 
In part, what makes gender-biased selection problematic in India is defined by the context in which it occurs. A practice gains meaning as discriminatory in the context in which it occurs. In India, sex selection may be discriminatory because it occurs in the context of gender inequalities such as son preference, dowry, a patrilocal system wherein the daughter physic ally leaves her parents' family and joins her husband's family after marriage, and inheritance traditions that favor sons. Those contextual societal motivations for sex selection are not present in the United States. If one accepts the facts that I have presented, it seems clear that the costs of the sex-selective abortion prohibitions do not exceed the costs.

There are several other approaches that the Court could take. It might not distinguish between previability and post-viability sex selective abortion bans and instead, apply the same legal test to both periods. It could categorically reject sex-selective abortion bans at all times during the pregnancy. Unlike the abortion prohibitions that the Court has previously considered, the sex-selective abortion laws are complete bans rather than "obstacles" to obtaining abortions. For example, the state legislation at issue in Casey merely created obstacles to a w oman's path to an abortion. ${ }^{87}$ The sex-selective bans do more than that - they prohibit abortion altogether for a specific reason. Alternatively, the Court could apply the "undue burden" test to both the pre-viability and post-viability period.

Another issue that the Court might consider is whether a fetus should have a legal right to be free from discrimination. No Americ an court has found that a state has an interest in protecting a fetus from discrimination. Indeed, in a concurring opinion, Justice Stevens has noted that "no member of [the Supreme Court] has ever suggested that a fetus is a 'person' within the meaning of the Fourteenth Amendment," which would entitle the fetus to equal protection of the law. ${ }^{88}$ If the Court were to extend this protection to a fetus, it would mean granting the fetus full personhood. To grant the fetus full personhood would open the door to a host of other abortion restric tions.

Bans on sex-selective abortion seem harmless. After all, most people do not approve of the practice. Very few w omen want to have an abortion for that purpose. But the right to choose could hinge on how the U.S. Supreme Court rules on sex-selective abortion bans if the is sue ever reaches the court. If the U.S. Supreme Court rules that sex-selective abortion bans are constitutional, this will invite more states to adopt a host of other reason-based pre-viability prohibition. For example, states could prohibit a woman from terminating her pregnancy if her reason is that she does not want to have a child born with a disability (assuming the fetus was diagnosed with a disability).

On the other hand, if the U.S. Supreme Court does not accept decontextualized arguments about the practice and instead relies on evidence-based research about sex-selective abortions in the United States, then they are more likely to find them unconstitutional. When the costs of sex-selective abortion bans are placed against an evidence-based and contextualized understanding of the benefits of such bans, it is clear that the costs far outweigh the benefits.

\section{Conclusion}

In recent years there has been a spate of anti-abortion legislation targeting sex-selective abortions. The strategic framing by pro-life advocates of such legislation in women's equality terms has created a situation where some pro-choice supporters of a woman's right to choose find themselves supporting (or at least, not strongly opposing) these bans. The dominant public narrative has centered on exploiting false assumptions about Asian Americ ans and exaggerating empirical data to fit those stereotypes. The dominant narrative is wrong. The practice of sex-selective abortion is not widespread in the United States among Asian Americans. Moreover, even if women do abort to sex-select (which we do not have conclusive evidence for), we cannot attribute the same motives to Asian women in the United States as 
we might attribute to women living in Asia. Sex-selective abortion bans are likely to be found unconstitutional if and when the question reaches the U.S Supreme Court, but this decision will no doubt turn on what set of facts the Court believes - the narrative that has gained popularity in the United States or the more nuanced approach I have suggested here. The story of sex-selective abortion laws is a reminder about the importance of carefully interrogating empirical data and challenging our own assumptions about minority and foreign peoples.

\footnotetext{
${ }^{1}$ Clinical Profes sor of Law, Cornell Law School. Full bio available at kalantry.lawschool.cornell.edu. I would like to thank Maithli Pradhan for herexcellent research work on this article.

${ }^{2}$ Sital Kalantry, Women's Human Rights and Migration: Sex-Selective Abortion Laws in the United States and India, 74(2017).

${ }^{3}$ Ed O'Keefe, Bill banning 'sex-selective abortions'fails in the House, The Washing ton Post, May 31, 2012, https://www.washingtonpost.com/blogs/2chambers/post/bill-banning-sex-selective-abortions-fails-in-thehouse/2012/05/31/gJQAgCYn4U blog.html?utm term=.45f2f7c1faf9.

${ }^{4}$ Lydia O'Connor, San Francisco May Be First City To Oppose Sex-SelectiveAbortion Bans, Huffington Post, Sept. 10, 2014, https://www.huffington post.com/2014/09/10/san-francisco-sex-selective-abortion_n_5800840.html. ${ }^{5}$ Illinois, 720 Ill. Comp. Stat. § 510/6-8 (2013); Pennsylvania, 18 Pa. Cons. Stat. § 3204 (2013); Oklahoma, Okla. Stat. Tit. 63, § 1-731.2 (2013); Arizona, Ariz. Rev. Stat. § 13-3603.02 (2013); Kansas, Kan. Stat. § 65-6726 (2013); North Carolina, N.C. Gen. Stat. § 90-21.121 (2013); North Dakota, N.D. Cent. Code § 14-02.1-04.1 (2013); South Dakota, H.B. 1162, 89th Leg., Reg. Sess. (S.D. 2014) (enacted); Indiana, Ind.Code § 16-34-4-1 (2016), Arkansas, H.B. 1434, 91st Leg., Reg. sess (Act 733).

${ }^{6}$ Illinois, 720 Ill. Comp. Stat. $\$ 510 / 6-8$ (2013) enjoined by Herbstv. O'Malley, No. 84C 5602, 1993 WL 59142 (N.D. Ill. Mar. 2, 1993); Indiana, Ind. Code § 16-34-4-1 (2016), enjoined by Planned ParenthoodofInd. \& Kyv. Comm'r, 2017 WL 4224750; Arkansas, H.B. 1434, 91st Leg., Reg. sess (Act 733) enjoined by Hopkins v. Jegley, 2017 WL 3220445, E.D. Ark. (2017).

${ }^{7}$ Douglas Almond \& Lena Edlund, Son-biased SexRatios in the 2000 United States Census, 105 Proc. Nat'l Acad. Sci. 5681, 5681 (2008), http://www.pnas.org/content/105/15/5681.full.pdf. ${ }^{8}$ Id.

${ }^{9}$ See Sital Kalantry, Sex-Selective Abortion Bans: Anti-Immigration or Anti-Abortion?, 16 Geo. J. Int'1 Aff. 140 (2015).

${ }^{10}$ See Sital Kalantry, Sex Selection in the United States and India: A Contextualist Feminist App roach, 18 UCLA Journal of International Law and Foreign Affairs (2013). State of Ill. Gen. Assemb., S. Trans cripts Discussing H.B. 1399, 83d Gen. Ass emb., at 36-38 (June 25, 1983); State of Ill. Gen. Assemb., S. Transcripts Discussing H.B. 1399, 83d Gen. Assemb., at 222-23 (June 29, 1983); State of Ill. Gen. As semb., S. Transcripts Dis cussing H.B. 1399, 83d Gen. Assemb., at 17-33 (Apr. 30, 1984); State of Ill. Gen. Assemb., S. Transcripts Discussing H.B. 1399, 83d Gen . Assemb., at 142-51 (June 30, 1984); State of Ill. Gen. Assemb., H. Transcripts Discussing H.B. 1399, 83d Gen. Assemb., at 175-79 (May 27, 1983); State of Ill. Gen. Assemb., H. Transcripts Discussing H.B. 1399, 83d Gen. Assemb., at 81-86 (Apr. 26, 1984); State of Ill. Gen. Assemb., H. Transcripts Discussing H.B. 1399, 83d Gen. Assemb., at 50-64 (June 29, 1984); H.R. 173-65, 1989 Sess., at 1743-44 (Pa. 1989), http://www.legis.state.pa.us /WU01/LI/HJ/1989/0/19891024.pdf (last visited June 7, 2015).

${ }^{11}$ H.R. 173-65, 1989 Sess., at 1749 (Pa. 1989), http://www.legis.state.pa.us/WU01/L//HJ/1989/0/19891024.pdf (last visited October 30, 2017).

${ }^{12}$ Prenatal Nondiscrimination Act(PRENDA) of 2017, H.R. 147, 115th Cong. § 2(a)(1)(F).

${ }^{13}$ Prenatal Nondiscrimination Act (PRENDA) of 2017, H.R. 147, 115th Cong. § 2(a)(1)(F).

${ }^{14}$ H.B. 845, 2013 Leg., Reg. Ses s. (Fla. 2013)

${ }^{15}$ Clifford GeERTZ, The InTERPRet ATION OF Culture 44 (1973).

${ }^{16}$ Molly Redden, GOP Lawmaker: We Need to Ban Sex-Selective Abortions Because of Asian Immigrants, Mother Jones (Feb. 25, 2014), http://www.motherjones.com/politics/2014/02/south-dakota-stace-nels on-ban-sex-b asedabortions-because-asian-immigrants (last visited May 29, 2015).

${ }^{17}$ See e.g., Ariz. Rev. Stat. § 13-3603.02 (2013).

${ }^{18}$ S.D. Codified Laws $\S 34-23 \mathrm{~A}-56$ (4A) (2014).

${ }^{19}$ Okla. Stat. Ann.tit. 63, § 1-738k (2013).

${ }^{20}$ Ariz. Rev. Stat. Ann. § 36-2157 (2011).

${ }^{21}$ Ariz. Rev. Stat. § 13-3603.02 (2013).
} 
${ }^{22}$ H.B. 1434, 91st Leg., Reg. sess (Act 733).

${ }^{23}$ Kate Sheppard, House GOP's 'Prenatal Nondiscrimination' Bill Fails, Mother Jones, May 31, 2012, www.motherjones.com/politics/2012/05/house-gop-abortion-sex-s election/.

${ }^{24}$ John Barrow on Abortion, OnTheIssues, www.ontheissue s.org/GA/John_Barrow.htm(last visited October 30, 2017); Dan Boren on Abortion, OnTheIssues, http://www.ontheissues.org/House/Dan_Boren.htm(last visited October 30, 2017); Henry Cuellar on Abortion, OnTheIssues, http://www.ontheissues.org/TX/Henry Cuellar.htm (last vis ited October 30, 2017); Mike Ros s on Abortion, OnTheIssues, www.ontheis sues.org/House/Mike_Ross.htm (last visited October 30, 2017); Roy Cooper on Abortion, OnTheIssues, http://www.ontheissues.org/Roy_Cooper.htm(last visited October 30, 2017); Steve Lynch on Abortion, OnTheIssues, http://www.ontheis sues.org/MA/Steve_Lynch.htm(last visited October 30, 2017); Jim Matheson on Abortion, OnTheIssues, http://www.ontheissues.org/House/Jim_Matheson.htm(last visited October30, 2017); Silvestre Reyes on Abortion, OnTheIssues, http://www.ontheissues.org/TX/Silvestre_Reyes.htm(last visited October 30, 2017).

${ }^{25}$ Representative Kissel from North Carolina and Representative Garamendi from California: Franco Ordonez, In Congress, Democrat Kis sell is stuck in the middle, Miami Herald, Nov.2, 2012, www.miamiherald.com/latestnews/article 1944175.html; John Garamendi on Abortion, OnTheIssues, www.ontheissues.org/CA/John_Garamendi.htm(last visited October 30, 2017).

${ }^{26}$ John Garamendi on Abortion, OnTheIssues, www.ontheissues.org/CA/John_Garamendi_Abortion.htm(last visited October 30, 2017).

${ }^{27}$ See Sital Kalantry, Women's Human Rights and Migration: Sex-Selective Abortion Laws in the United States and India, 85-87 (2017).

${ }^{28}$ See e.g., Noah Berlatsky, Neither Pro-Life Nor Pro-Choice Can Solve the Selective Abortion Crisis, The Atlantic, March 6, 2013, https://www.theatlantic.com/sexes/archive/2013/03/neither-pro-life-nor-pro-choice-can-solve-theselective-abortion-crisis/273704/.

${ }^{29}$ Chris Bodenner, The Gendercide Crisisin Asia, AtLantic (May 23, 2016, 12:25 PM), http://www.theatlantic.com/notes/2016/05/abortion/483866/.

${ }^{30}$ The sex ratio is the ratio of males to females in any given population (males per 100 females).

${ }^{31}$ Douglas Almond \& Lena Edlund, Son-Biased Sex Ratios in the 2000 United States Census, 105 Proc. NAT'L ACAD. SCI. 5681, 5681 (2008), http://www.pnas.org/content/105/15/5681.full.pdf.

${ }^{32} I d$.

${ }^{33} I d$.

${ }^{34}$ Male Birth Rate Among Asian Americans Studied, NPR (Apr. 1, 2008), http://www.npr.org/templates/story/story.php?storyId=89284549.

${ }^{35}$ See Sam Roberts, U.S. As ians Show Bias for Boys; Census Data on Births Also Reflects Embrace of Sex

Selection, Experts Say, INT'L Herald TriB., June 16, 2009, at 2; See also U.S. Births Hint at Bias for Boys in Some Asians, NYTimes, June 14, 2009, www.nytimes.com/2009/06/15/nyregion/15babies.html; .

${ }^{36}$ See William Saletan, Fetal Subtraction, Slate (Apr. 3, 2008), http://www.slate.com /articles/health_and_science/human_nature/2008/04/fetal_subtraction.html.

${ }^{37}$ Douglas Almond \& Lena Edlund, Son-biased SexRatios in the 2000 United States Census, 105 Proc. Nat'l Acad. Sci. 5681, 5681 (2008), http://www.pnas.org/content/105/15/5681.full.pdf.

${ }^{38}$ See William Saletan, Fetal Subtraction, Slate (Apr. 3, 2008), http://www.slate.com /articles/health and science/human nature/2008/04/fetal subtraction.html. ("Sex selection of this magnitude has previously been documented in China, South Korea, and India, but not in the United States.")

${ }^{39}$ Almond \& Edlund, supra note 30, at 5681.

${ }^{40} \mathrm{Id}$.

${ }^{41} I d$.

${ }^{42} I d$.

${ }^{43} I d$.

${ }^{44} \mathrm{Jae}$ Woo Lim, The Changing Trends in Live Birth Statistics in Korea, 1970 to 2010, 54 Korean J. Pediatric 429 (2011), http://www.ncbi.nlm.nih.gov/pmc/articles/PMC3254888/.

${ }^{45}$ See Woojin Chung \& Monica Das Gupta, Why Is Son Preference Declingin in South Korea? The Role of Development and Public Policy, and the Implications for China and India (World Bank, Working Paper No.4373, 2007), https://openknowledge.worldbank.org/bitstream/handle/109867/7367/wps4373.pdf? sequence=1.

${ }^{46}$ See eg., Jason Abrevaya, Are There Missing Girls in the United States? Evidence fromBirth Data, 1 Am. Econ. J.: Applied Econ. 1, 23 (2009). 
${ }^{47}$ James F.X. Egan et al., Dis tortions of Sex Ratios at Birth in the United States: Evidence for Prenatal Gender Selection, 31 PrenatalDiagnosis 560, 565 (2011).

${ }^{48}$ Elizabeth M. Hoeffelet al., The Asian Population:2010, in 2012 Census Briefs, U.S. Census Bureau 1, 14 (2012), http://www.census.gov/prod/cen2010/briefs/c2010br-11.pdf.

${ }^{49}$ Sunny Hundal, India's 60 million women that never were, Al Jazeera, Aug. 8, 2013, www.aljazeera.com/indepth/opinion/2013/07/201372814110570679.html.

${ }^{50}$ See Molina B. Dayalet al., Preimplantation Genetic Diagnosis, Medscape, Dec. 30, 2015, https://emedicine.medscape.com/article/273415-overview (last visited October 30, 2017).

${ }^{51}$ See Tufuku Zuberi \& Eduardo Bonilla-Silva, Towards a Definition of White Logic and White Methods, in WhITE

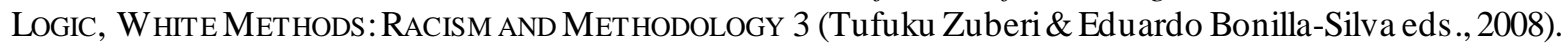

${ }^{52}$ See e.g. Sus an Moller Okin, Is Multiculturalism Bad for Women?, in Is Multiculturalis mBad for Women? 7 (Princeton Univ. Press 1999), in which Okin lis ts many practices and ways in which minority and immigrant cultures are repressive to women.

${ }^{53}$ See e.g, Leti Volpp, Blaming Culture for Bad Behavior, 12 YALE J.L. \& Human. 89 (2000).

${ }^{54}$ While gender-biased sexs election als o occurs in China, given my knowledge, I include only a detailed examination of the factors that lead to sexselection in India

${ }^{55}$ See Mara Hvistendahl, Unnatural Selection 80 (2011), Christophe Z. Guilmoto, Characteristics of SEX-RATio Imbalance IN INDia, AND Future ScEnarios 4-8 (2007), http://www.unfpa.org/gender/docs/studies/india.pdf.

${ }^{56}$ See Ravinder Kaur, Mapping the Adverse Consequences of Sex Selection and Gender Imbalance in India and China, ECONOMIC \& Polit ICAL WeEKLY, August 2013 at 37; Ravinder Kaur, Too Many Men Too Few Women: Social Consequences of Gender Imbalance in India and China (2016); Scott J. South, Katherine Trent and Sunita Bose, Skewed Sex Ratios and Criminal Victimization in India, DEMOGRAPHY, June 2014 at 1019; Sofia Amaral and Sonia Bhalotra, Population sexratios and violence against women: The long-run effects of sexs election in India, Institute for Social \& Economic Research (2017), https://www.iser.essex.ac.uk/research/publications/workingpapers/iser/2017-12.pdf.

${ }_{57}^{5}$ See Sital Kalantry, Women's Human Rights and Migration: Sex-Selective Abortion Laws in the United States and India, 12-46, 152-175 (2017).

${ }^{58}$ The data grows out of work I have done with Miriam Yeung, Executive Director of the National Asian Pacific Women's Forum, Shivana Jorawar, Reproductive Justice Program Director, National Asian Pacific Women's Forum, Sujatha Jesudason, Director of CoreAlign at the University of California, San Francisco, and Brian Citro, Clinical Lecturer in Law, University of Chicago Law School.

${ }^{59}$ See Frank Newport, Americans Prefer Boys to Girls, Just as They Did in 1941, Gallup (June 23, 2011), http://www.g allup.com/poll/148187/americans-prefer-boys-girls-1941.aspx.

${ }^{60}$ Hoeffel et al., supra note 16 , at 7 .

${ }^{61}$ See generally Judith Butler, Gender TROuble: Feminism AND THE SubVERSION OF IDENTITY (2006).

${ }^{62}$ See Jonathan M. Berkowitz \& Jack W. Snyder, Racism and Sexism in MedicallyAssisted Conception, 12 BIOETHICS 25 (1998). Others have argued that the concept of family balancing creates this idea that an appropriate family has at least one boy and one girl. Soren Holm, Like a Frog in Boiling Water: The Public, the HFEA, and Sex Selection, 12 Health Care Analysis, 27 (2004).

${ }^{63}$ There was a moment in the early 1990s when Planned Parenthood could havebrought this question to the Court when it sued the state of Pennsylvania challenging a hos tof anti-abortion res trictions the statehad enacted in 1988 and 1989. A prohibition on sex-selective abortion was one of those restrictions. See 18 PA. Cons. STAT. § 3204(c) (2013). But Planned Parenthood did not challenge that particular res triction in 1990 when it challenged other antiabortion restrictions. 744F. Supp. 1323 (ED Pa. 1990).

${ }^{64}$ See Bans on Sex-Selective Abortions: How Far Is Too Far?, 40 Hastings ConsT. L.Q. 423 (2013) (arguing that sex-s elective bans infringe on women's constitutional right to privacy and liberty, fail Casey's undue burden test becau se they completely ban abortion based on sex, and differ from Gonzales as there are no alternative methods of abortion; in addition, there is no precedent of the court having limited a woman's reas ons for seeking an abortion); Justin Gillette, Pregnant and Prejudiced: The Constitutionality of Sex-AndRace-Selective Abortion Restrictions, 88 W ASH. L. REV. 645 (arguing that motive-based abortion restrictions, such as sex-selective abortion bans, are unconstitutional because they violate a woman's constitutional liberty rights - although Gillette notes that the Supreme Court has allowed increasingly restrictive abortion laws since Roe); Jaime Staples King, Not This Child: Constitutional Questions In Regulating Noninvasive Prenatal Genetic Diagnosis And Selective Abortion, 60 UCLA L. REV. 2(2012) (arguing that the right to choose abortion for any reason should be grounded in the principles of 
liberty and autonomy, rather than sexequality and that sex-selective abortion bans would fail the undue burden test because women would need to withhold information from their doctors or opt not to have abortions); Mary Kanows ky, A Hidden Gendercide: Discrepancies Between Embryo Destruction and SexSelective Abortion Laws, 14 A VE MARIA L. REV. 163 (2016) (arguing that using a gender equality framework, it remains unclear whether sexselective abortion bans would be constitutional because it is unclear what standard of scrutiny would apply, that under a right to privacy argument such bans fail the undue burden test prior to viability, and that under Cas e, postviability bans would be unconstitutional because they not leave exceptions for the health of the mother); Kris sa Webb, Gender Mis-Conception: The Prenatal Nondiscrimination Act as A Remix of the Abortion Debate, 11 GEO. J.L. \& PUB. POL'Y 257 (2013) (arguing thatfederal regulations on sex-selective abortion should be constitutional and would likely be justifiable if imposed on state-run medical centers or as an issue of private discrimination by the medical industry that has a substantial effect on interstate commerce); Jason C. Greaves, Sex-SelectiveAbortion in the U.S.: Does Roe v. Wade Protect Arbitrary Gender Discrimination?, 23 GEO. MASON U. Civ. RTs. L.J. 333, 363 (2013) (concluding that current juris prudence does not seemto allow for sex-selective abortion bans under the fundamental right to privacy, but that public opinion may influence the court's decision); Thomas J. Molony, Roe, Casey, and Sex-Selection Abortion Bans, 71 W ASH. \& LEE L. REV. 1089 (2014) (differentiating between narrow bans that ban abortion based solely on sex, and broader bans that proscribe abortions when sexselection is one of other reas ons and that do notcontain a life or health exception and arguing that in light of Gonzales, a narrowly drafted sex-selective abortion ban that does not include life or health exceptions could survive a challenge despite the Casey ruling). See also Greer Donley, Does the Constitution Protect Abortions Based on Fetal Anomaly?: Examining the Potential for Disability-selective Abortion Bans in the Age of Prenatal Whole Genome Sequencing, 20 MICH. J. GENDER \& L. 291 (2013) (presenting an analysis of the unconstitutionality of disability-selective abortion bans under the Commerce Clause and the Equal Protection Clause and highlighting the slip pery slope argument that may be illuminating when considering sex-selective abortion bans).

${ }^{65}$ The sex of a fetus could be determined using blood tests of the pregnant woman's blood as early as seven weeks of gestation ${ }^{65}$ or as early as twelve weeks using an ultrasound. ${ }^{65}$

${ }^{66}$ Whole Woman's Health v. Hellerstedt, 579 U.S. __ (2016).

${ }^{67}$ Whole Woman's Health v. Hellerstedt, 579 U.S. ${ }_{--}, 19-21$ (2016).

${ }^{68}$ See Ind.Code $\$ 16-34-4-1$ (2016). Dis ability-selective abortion bans prohibit a woman fromobtaining an abortion even if the fetus has a genetic anomaly such as Down syndrome. Race-selective abortion bans are designed to rectify what has long been a belief of the anti-abortion movement (as well as some African American groups and leaders): abortion providers target African Americans for abortion services in an attempt to reduce thenumber of African Americans that are born. However, the text of race-s elective abortion bans typically prohibit medical professionals from performing an abortion if the patient's motive in seeking the abortion is the race of the fetus. Even if antiabortion groups are right that abortion providers target minority women for abortions, it makes little sense to say that minority women obtain abortions because they object to therace of their own fetuses.

${ }^{69}$ Planned Parenthood of Ind. \& Ky v. Comm'r, 2017 WL4224750, 8.

${ }^{70}$ Planned Parenthood of Indiana, et al v. Commissioner of the Indiana St, et al, No. 17-3163, U.S. Court of Appeals, Seventh Circuit (Oct. 19, 2017).

${ }^{71}$ Roe v. Wade, 410 U.S. 113 (1973).

${ }^{72}$ Roe v. Wade, 410 U.S. 113, 164-65 (1973).

${ }_{73}^{73}$ Planned Parenthood of Ind.\& Ky v. Comm'r, 2017 WL4224750, 5 (citing Planned Parenthood v. Casey, 505 U.S. 833, 870 (1992)).

${ }^{74}$ Herbst v. O'Malley, No. 84 C 5602, 1993 WL 59142 (N.D. Ill. Mar. 2, 1993).

${ }^{75}$ Herbst, 1993 WL 59142, at 9.

${ }^{76}$ Isaacs on v. Horne, 716F.3d 1213, 1231 (9th Cir. 2013).

${ }^{77}$ Planned Parenthood of Southeastern Pennsylvania v. Casey, 505 US 833 (1992).

${ }^{78}$ Whole Woman's Health v. Hellers tedt, 579 U.S.

${ }^{79} \mathrm{Id}$. at 1 .

${ }^{80} \mathrm{Id}$. at $1-2$.

${ }^{81} I d$. at 2.

${ }^{82} I d$. at $19-21$.

${ }^{83} \mathrm{Id}$. at 6.

${ }^{84} I d$. at 26.

${ }^{85} \mathrm{Id}$. at $20-21$.

${ }^{86} \mathrm{Id}$. at 21-36. 
${ }^{87}$ Planned Parenthood of Southeastern Pennsylvania v. Casey, 505 US 833 (1992).

${ }^{88}$ See, e.g., Thornburgh v. American College of Obstetricians \& Gynecologists, 476 U.S. 747, 779 n.8 (1986). 